DOI: $10.33766 / 25240323.88 .278-287$

УДК 347.963

Д. Ю. Фурсов,

аспірант кафедри організації правоохоронних та судових органів Луганського державного університету внутрішніх справ імені Е. О. Дідоренка

(м. Сєвєродонецьк, Україна) e-mail:fur_dima@ukr.net

(iDhttps://orcid.org/0000-0002-0891-905

\title{
СУТНІСТЬ, ПРЕДМЕТ ТА МЕЖІ ПРОКУРОРСЬКОГО НАГЛЯДУ ЗА ДОДЕРЖАННЯМ ЗАКОННОСТІ ПІД ЧАС ДОСУДОВОГО РОЗСЛІДУВАННЯ КРИМІНАЛЬНИХ ПРАВОПОРУШЕНЬ ПРОТИ БЕЗПЕКИ ДОРОЖНЬОГО РУХУ
}

У статті досліджено засадничі основи теорії прокурорського нагляду, на підставі чого сформульовано поняття сутності, предмету, об'єкту та меж прокурорського нагляду за додержанням законності під час досудового розслідування кримінальних правопорушень проти безпеки дорожнього руху, а саме злочинів, передбачених ст. 286 КК України. Сформовано та проаналізовано принципи процесуальної діяльності слідчого, які $є$ елементом предмету прокурорського нагляду за додержанням законності під час досудового розслідування кримінальних правопорушень проти безпеки дорожнього руху (ст. 286 КК України).

Ключові слова: прокурор, процесуальне керівництво, прокурорський нагляд, до судове розслідування, дорожньо-транспортна пригода.

Постановка проблеми. Дорожньо-транспортний травматизм, за даними BOO3, наразі є однією з найбільших світових проблем охорони здоров'я. За прогнозами, у 2030 році ДТП може стати однією з основних п'яти причин смертності людей у світі. У свою чергу, ДТП в Україні є першою за поширеністю причиною смерті молоді віком від 15 до 24 років та другою за поширеністю причиною смерті дітей віком від 5 до 14 років [1]. Подолання наслідків цих негативних явищ (зменшення кількості ДТП, мінімізація травматизму та смертності на дорогах України, відшкодування збитків від ДТП тощо) значною мірою залежить від результативності діяльності прокурора, зокрема ефективності прокурорського нагляду за додержанням законності під час досудового розслідування кримінальних правопорушень проти безпеки дорожнього руху. У зв'язку з вищевикладеним, виникає проблема з'ясування сутності, предмету та меж прокурорського нагляду за додержанням законності під час досудового розслідування кримінальних правопорушень проти безпеки дорожнього руху, а саме злочинів, передбачених ст. 286 КК України.

Аналіз останніх досліджень і публікацій. Окремі аспекти зазначеної проблематики вже аналізувалися В. В. Білоусом, Р. М. Білоконем, П. Є. Власовим, А. А. Вознюком, В. О. Гапчичем, Л. Р. Грицаєнком, А. А. Дворником, В. С. Зеленецьким, С. О. Іваницьким, П. М. Каркачем, В. Г. Клочковим, І. М. Козьяковим, М. И. Курочкою, А. В. Лапкіним, В. Т. Маляренком, В. П. Півненком, М. В. Руденком, А. Б. Степановим, 
M. М. Стефанчук та іншими, проте сутність, предмет, об'єкт та межі прокурорського нагляду за додержанням законності під час досудового розслідування кримінальних правопорушень проти безпеки дорожнього руху комплексно на науковому рівні не вивчалися, що зумовлює актуальність обраної теми дослідження.

Формування цілей. Метою дослідження є з'ясування сутності, предмета та меж прокурорського нагляду за додержанням законності під час досудового розслідування кримінальних правопорушень проти безпеки дорожнього руху, а також удосконалення правової регламентації пов' язаних із цим питань.

Виклад основного матеріалу. У доктрині прокурорського нагляду відсутне визначення сутності прокурорського нагляду. Згідно з академічним тлумачним словником української мови, поняття «сутність» являє собою «головне, визначальне в предметі, щуо зумовлене глибинними зв'язками й тенденціями розвитку і пізнається на рівні теоретичного мислення; основне, істотне в кому-, чомунебудь, зміст чогось»[2, с. 860]. Таким чином, можна дійти висновку, що сутність прокурорського нагляду - це основа прокурорського нагляду, те, з чого він складається (зміст).

В. П. Півненко під сутністю прокурорського нагляду розуміє встановлений Основним Законом України специфічний і самостійний вид державної правоохоронної діяльності, який від імені держави здійснюється Генеральним прокурором України й підпорядкованими йому прокурорами шляхом гласного (відкритого) спостереження (нагляду) 3 метою забезпечення однакового розуміння, додержання та правильного застосування Конституції і законів України на всій території країни, тобто направлений на утвердження верховенства права, захист і відновлення порушених прав і законних інтересів людини, суспільства і держави [3, с. 18-19].

М. Й. Курочка та П. М. Каркач вважають, що сутність прокурорського нагляду - це специфічна діяльність державних органів прокуратури, яка здійснюється від імені України та полягає в перевірці точності додержання Конституції України й виконання законів, які діють на її території. Змістом цієї діяльності є таке: виявлення фактів порушення Конституції та вимог законів, установлення винних у правопорушеннях, ужиття заходів щодо усунення порушень закону й поновлення порушених прав, притягнення в установленому законом порядку до відповідальності осіб, які порушили закон $[4,5]$.

А. Б. Степанов виділяє сутнісні ознаки діяльності прокурора під час досудового розслідування кримінальних правопорушень, а саме: єдність спрямованості процесуальної діяльності прокурора та слідчого у формуванні публічного обвинувачення; систематичність перевірки законності здійснення органом досудового розслідування його процесуальної функції; наявність владних повноважень, що дозволяють здійснювати оперативне втручання в процесуальну діяльність слідчого за наявності передбачених у законі підстав; можливість прийняття процесуального рішення, замість підконтрольного суб'єкта, до повноважень якого належить здійснення досудового розслідування [5, с. 64-65]. 
Змістом прокурорського нагляду за додержанням законності під час досудового розслідування кримінальних правопорушень проти безпеки дорожнього руху є таке:

- виявлення фактів порушення законів слідчим під час досудового розслідування зазначеної категорії кримінальних правопорущень. До ряду таких недоліків належить, зокрема порушення права на захист під час проведення слідчих дій, адже, як стверджує С. О. Іваницький, важливою складовою наглядової роботи прокурора є перевірка додержання права особи на захист [6, с. 105]. Важливість зазначеного напряму роботи прокурора підтверджується тим, що, згідно 3 п. 3 ч. 2 ст. 87 КПК України, порушення права особи на захист є підставою для визнання недопустимими доказів, отриманих у результаті слідчої дії. Неякісний контроль щодо виявлення фактів порушення законів слідчим може призвести до непереборних наслідків й ухвалення виправдувального вироку;

- спрямування ходу розслідування та перевірка правильності, обгрунтованості та своєчасності встановлення осіб, у діях яких вбачається склад злочину, передбаченого ст. 286 КК України;

- ужиття заходів стосовно поновлення порушених прав, щуо були обмежені під час досудового розслідування кримінальних правопорушень, передбачених ст. $286 \mathrm{KK}$ Украӥни (порушення правил безпеки дорожнього руху або експлуатації транспорту особами, які керують транспортними засобами). Проілюструємо це на прикладі. У ході досудового розслідування кримінальних правопорушень проти безпеки дорожнього руху (ст. 286 КК України) виникає необхідність у накладанні арешту на транспортний засіб, водій якого став учасником ДТП. У цьому випадку метою накладання арешту є збереження речових доказів [7, с. 228]. Накладання арешту - це не забаганка органів кримінального переслідування, а безальтернативна необхідність, оскільки автомобіль - це матеріальний об'єкт, який був знаряддям вчинення кримінального правопорушення та зберігає на собі сліди, які можуть бути використані як доказ факту чи обставин, що встановлюються під час кримінального провадження. Згідно зі ст. 170 КПК України, накладання арешту тягне порушення прав власника автомобіля на відчуження, розпорядження та користування транспортним засобом. Після проведення всіх необхідних слідчих дій із транспортним засобом (судові експертизи, слідчий експеримент), а також інших процесуальних дій перед прийняттям рішення, за ст. 284 КПК України, процесуальний керівник повинен звертати увагу слідчого на необхідність ужиття заходів щодо поновлення порушених прав власника автомобіля, а саме роз'яснення власнику транспортного засобу процедури відновлення його прав (п. 2. ч. 1 ст. 174 КПК України).

- перевірка дотримання слідчим законів під час прийняття рімень (за ст. 290 чи ст. 284 КПК України).

Таким чином, сутність прокурорського нагляду за додержанням законності під час досудового розслідування кримінальних правопорушень проти безпеки дорожнього руху полягає в тому, щуо иее специирічний і самостійний вид державної правоохоронноі діяльності, який від імені держави здійснюється прокурором - процесуальним керівником - та направлении на виявлення порушень законів під час досудового розслідування; спрямування ходу розслідування та перевірку правильності, 
обтрунтованості та своєчасності встановлення осіб, у діях яких вбачається склад злочину, передбаченого ст. 286 КК України; ужиття заходів щодо поновлення порушених прав, які були обмежені в результаті досудового розслідування; перевірку дотримання слідчим законів під час прийняття рімень (за ст. 290 чи ст. 284 КПК України.)

Перш ніж перейти до предмету прокурорського нагляду у сфері, що розглядається, доцільно розглянути співвідношення понять предмету та об'єкту прокурорского нагляду. Зазначене питання є дискусійним у науці. Так, наприклад, Л. Р. Грицаєнко не розмежовує ці дефініції, використовуючи їх як взаємозамінювані [8, с. 168]. Ми, у свою чергу, дотримуємося загальнофілософської позиції про предмет як категорію, що утворена певною цілісністю, виокремленою зі світу об'єктів у процесі людської діяльності й пізнання, тому предмет та об'єкт прокурорського нагляду розглядаємо як окремі поняття.

Відповідаючи на питання, що таке предмет прокурорського нагляду, слід розуміти, що «ие те, на що направлено нагляд». Згідно зі ст. 25 Закону України №1697-VII від 14 жовтня 2014 року «Про прокуратуру», законодавець визначає предметом нагляду додержання законів органами, що провадять досудове слідство. Ми підтримуємо позицію, у відповідності до якої предметом прокурорського нагляду за додержанням законів органами досудового розслідування $є$ дотримання останніми законів під час прийняття процесуальних рішень і вчинення процесуальних дій, положень Конституції України, КПК України, інших законодавчих актів, а також міжнародноправових договорів та угод, учасником яких є Україна [9, с. 17]. Разом із тим, формулюючи поняття предмету прокурорського нагляду за додержанням законності під час досудового розслідування кримінальних правопорушень проти безпеки дорожнього руху (ст. 286 КК України), зазначимо, що, згідно зі ст. 36 КПК України, прокурор здійснює нагляд за додержанням законів під час проведення досудового розслідування у формі процесуального керівництва.

За результатами аналізу прокурорської практики необхідно констатувати, що важливими складовими керівництва є спрямування та координація дій слідчого на забезпечення законного, повного, неупередженого, швидкого, усебічного та ефективного проведення досудового розслідування.

Отже, на нашу думку, предметом прокурорського нагляду за додержанням законності під час досудового розслідування кримінальних правопорушень проти безпеки дорожнъого руху (ст. 286 КК України) є дотримання слідчими Національноі поліції України норм кримінального процесуального та іншого законодавства України, відповідність їх процесуальних діӥ $i$ рішень принципам повноти, швидкості, неупередженості та ефрективності розслідування.

Зауважимо, що діяльність прокурора, яка направлена на контроль за відповідністю процесуальних дій та рішень слідчого принципам повноти, швидкості, неупередженості, ефективності розслідування $є$ основним елементом наглядової діяльності прокурора за процесуальною роботою слідчого в процесі досудового розслідування кримінальних правопорушень проти безпеки дорожнього руху (ст. 286 КК України), оскільки точна та 
неухильна реалізація слідчим указаних засад дозволить органам кримінального переслідування встановити істину в справі. Пояснимо далі на прикладах.

1. Принциип повноти ходу розслідування. Аналізуючи слідчу та прокурорську практику досудового розслідування кримінальних правопорушень проти безпеки дорожнього руху (ст. 286 КК України), можна дійти висновку, що зазначена категорія кримінальних правопорушень відрізняється великою варіативністю слідчих версій. Учасниками та свідками ДТП може бути велика кількість людей (водії, пішоходи, свідки ДТП, потерпілі), що, у свою чергу, може утворювати велику кількість версій скоєного злочину. Тому процесуальний керівник повинен слідкувати за тим, щоб слідчий у ході досудового слідства перевіряв на вірогідність всі можливі версії та враховував їх під час призначення автотехнічної експертизи.

2. Приниип неупередженості розслідування. Слідчий у своїй діяльності повинен бути неупереджений, адже злочини проти безпеки дорожнього руху (ст. 286 КК України) належать до тих категорій кримінальних правопорушень, що характеризуються підвищеним рівнем корупціогенності, тому прокурор повинен ретельно контролювати процесуальну діяльність слідчого й знати про всі слідчі (розшукові) дії та прийняті процесуальні рішення, перевіряти зміст, правильність складання та якість процесуальних документів (відповідність дійсності встановлених вихідних даних у ході допитів та слідчих експериментів, внесення правдивих та точних вихідних даних до постанови про призначення автотехнічної експертизи тощо) 3 метою попередження й унеможливлення корупційних проявів у роботі слідчого. Зауважимо, що $b$ разі виникнення $b$ процесуального керівника сумнівів щодо об'єктивності проведення слідчим слідчої дії, для усунення сумнівів прокурор за своєю участю у найкоротший час обов' язково повинен провести зазначену слідчу дію із зазначеним учасником. У разі виявлення порушення Вимоги неупередженості слідчим під час досудового слідства, процесуальний керівник повинен вжити заходів щодо притягнення останнього до кримінальної чи дисииплінарної відповідальності (залежно від ситуаціі, що склалася) або діяти відповідно до п. 8 ч. 2 cm. 36 КПК України, а саме: ініціювати перед керівником органу досудового розслідування питання про відсторонення слідчого від проведення досудового розслідування та призначення іншого слідчого за наявності підстав, передбачених КПК України, для його відводу або у випадку неефективного досудового розслідування [10].

3. Приниип швидкості ходу розслідування. Процес розслідування кримінальних правопорушень проти безпеки дорожнього руху (ст. 286 КК України) є дуже специфічним. Першочергового значення набуває швидкість та невідкладність проведення слідчих дій, що зумовлено тактикою та методикою розслідування зазначеної категорії кримінальних правопорушень. Наприклад, у ході розслідування може виникати необхідність у проведенні слідчого експерименту, що, як відомо, проводиться, 3 метою перевірки й уточнення відомостей, які мають значення для встановлення обставин кримінального правопорушення. Слідчий, прокурор мають право провести слідчий експеримент шляхом відтворення дій, обстановки, обставин певної події, проведення необхідних дослідів чи випробувань (ст. 240 КПК України). Отже, при проведенні слідчих експериментів під час розслідування зазначеної 
категорії кримінальних правопорушень, потрібно дотримуватися вимоги відповідності погодних та дорожніх умов тим, які були під час ДТП (сніг, дощ, наявність листя на деревах тощо), у зв'язку з чим прокурор повинен звертати увагу слідчого на швидкість та невідкладність виконання зазначених слідчих дій. Неякісний контроль та зволікання $з$ їх проведенням може призвести до негативних наслідків та тяганини в процесі розслідування злочинів проти безпеки дорожнього руху.

4. Принцип ефективності. Процесуальний керівник повинен контролювати ефективність проведення слідчим слідчих дій. Прокурор має слідкувати за тим, щоб слідчий планував власні слідчі дії та якісно виконував свою процесуальну роботу (перевірка плану проведення слідчої дії, вивчення питань, які слідчий планує ставити в ході проведення слідчої дії тощо). Невиконання цього принципу може затягнути хід досудового розслідування та завести його в т. зв. «глухий кут».

У теорії прокурорського нагляду є різні підходи щодо змісту поняття «об'єкт прокурорського нагляду». На думку І. І. Когутича, В. Т. Нора, А. А. Павлишина, Л. Р. Грицаєнка та ін., об'єкт прокурорського нагляду становлять міністерства, відомства, установи, підприємства, організації, органи й посадові особи, на яких поширюються наглядові повноваження прокурора [11, с. 13; 8, с. 16]. О. Р. Михайленко розкриває сутність об'єкту прокурорського нагляду через поведінку (діяльність, бездіяльність, результати, наслідки) суб'єктів, що має юридичне значення [12, с. 144]. Відповідно до статті 216 КПК України, слідчі органів Національної поліції здійснюють досудове розслідування кримінальних правопорушень, передбачених статтею 286 КК України (порушення правил безпеки дорожнього руху або експлуатації транспорту особами, які керують транспортними засобами).

Отже, об'єктом прокурорського нагляду за додержанням законів під час розслідування кримінальних правопорушень проти безпеки дорожнього руху (ст. 286 КК України) виступають підрозділи досудового розслідування органів Національної поліції, зокрема слідчі відділи з розслідування злочинів у сфері транспорту слідчих управлінь (відділів) Головних управлінь Національної поліції України, уповноважені слідчі слідчих відділів (відділень) поліції районного (міського) рівня. Важливим питанням є правильне визначення меж прокурорського нагляду за додержанням законності під час досудового розслідування кримінальних правопорушень проти безпеки дорожнього руху. Ми підтримуємо позицію А. А. Дворника стосовно того, що межі прокурорського нагляду дозволяють окреслити компетенцію прокурорів із здійснення нагляду з точки зору встановлення групи нормативних актів, точне виконання яких складає предмет прокурорського нагляду, кола органів, законність діяльності яких підпорядкована прокуратурі, а також обсягу повноважень прокурорів [13, с. 33]. Таким чином, межі прокурорського нагляду за додержанням законності під час досудового розслідування кримінальних правопорушень проти безпеки дорожнього руху є правовою категорією, що дозволяє окреслити компетенцію прокурорів із здійснення нагляду з точки зору встановлення групи нормативних актів, точне виконання яких складає предмет прокурорського нагляду в цій сфері; кола органів, законність діяльності яких 
підпорядкована прокуратурі, а також обсягу повноважень прокурорів, які здійснюють прокурорський нагляд за додержанням законності під час досудового розслідування зазначеної категорії кримінальних правопорушень. Детальну увагу кожному з окреслених вище елементів даної правової категорії ми плануємо приділити в наступних наукових статтях.

Висновки. Отже, прокурорський нагляд за додержанням законності під час досудового розслідування кримінальних правопорушень проти безпеки дорожнього руху (ст. 286 КК України) - це специфічний i самостійний вид державної правоохоронноі діяльності, який від імені держави здійснюється прокурором - процесуальним керівником -та направлений на виявлення порушень законів під час досудового розслідування; спрямування ходу розслідування та перевірку правильності, обгрунтованості та своєчасності встановлення осіб, у діях яких вбачається склад злочину, передбачений ст. 286 КК України; ужиття заходів щодо поновлення порушених прав, які були обмежені в результаті досудового розслідування; перевірку дотримання слідчим законів під час прийняття рішень (відповідно до ст. 290 чи ст. 284 КПК України).

Предметом прокурорського нагляду за додержанням законності під час досудового розслідування кримінальних правопорушень проти безпеки дорожнього руху (cm. $286 \mathrm{KK}$ України) $є$ дотримання слідчими Національної поліції України норм кримінального процесуального та іншого законодавства України, відповідність їхніх процесуальних дій i рішень принципам повноти, швидкості, неупередженості та ефективності розслідування.

Об'єктом прокурорського нагляду за додержанням законів під час розслідування кримінальних правопорушень проти безпеки дорожнъого руху (ст. 286 КК Украӥни) виступають підрозділи досудового розслідування органів Національної поліції, зокрема слідчі відділи з розслідування злочинів у сфері транспорту слідчих управлінь (відділів) Головних управлінь Національної поліції України, уповноважені слідчі слідчих відділів (відділень) поліції районного (міського) рівня.

Межі прокурорського нагляду за додержанням законності під час досудового розслідування кримінальних правопорушень проти безпеки дорожнього руху - це правова категорія, що дозволяє окреслити компетенцію прокурорів із здійснення нагляду з точки зору встановлення групи нормативних актів, точне виконання яких складає предмет прокурорського нагляду за додержанням законності під час досудового розслідування кримінальних правопорушень проти безпеки дорожнього руху, коло органів, законність діяльності яких піднаглядна прокуратурі, а також обсягу повноважень прокурорів, які здійснюють прокурорський нагляд за додержанням законності під час досудового розслідування зазначеної категорії кримінальних правопорушень.

\section{Використані джерела:}

1. Безпека на дорозі стосується кожного. В Україні стартував тиждень безпеки дорожнього руху ООН: Міністерство Охорони Здоров'я України: URL: https:/ / moz.gov.ua/article/news/bezpeka-na-dorozi-stosuetsja-kozhnogo-v-ukrainistartuvav-tizhden-bezpeki-dorozhnogo-ruhu-oon (дата звернення: 19.11.2019) 
2. Словник української мови: в 11 тт. / за ред. І. К. Білодіда. Київ: Наукова думка, 1970-1980. T. 9.

3. Півненко В. П. Прокурорський нагляд в Україні: навч. посіб. Харків: Харків Юридичний, 2008. 304 с.

4. Курочка М. Й., Каркач П. М. Прокурорський нагляд в Україні: підручник. за ред. Е. О. Дідоренка. Луганськ: РВВ ЛДУВС, 2004. 424 с.

5. Степанов А.Б. Співвідношення прокурорського нагляду, відомчого та судового контролю під час досудового розслідування: дис. .. канд. юрид. наук: 12.00.09/ Національний юридичний університет ім. Ярослава Мудрого. Харків, 2018. 181c.

6. Іваницький С. О. Роль прокурора в забезпеченні законності затримання особи за підозрою у вчиненні злочину. Вісник Луганського державного університету внутрішніх справ імені Е. О. Дідоренка. 2018. № 4. С. 102-108.

7. Фаринник В. I. Теоретичні, правові та праксеологічні проблеми застосування заходів забезпечення кримінального провадження в кримінальному процесі України: дис. ...док. юрид. наук: 12.00.09/ Київський національний університет імені Тараса Шевченка. Київ. 2018. 585 с.

8. Грицаєнко Л. Р. Конституційно-правовий статус прокуратури України: підручник. Київ: Біноватор, 2007. 544 с.

9. Мельник О. В. Проблеми прокурорського нагляду за додержанням законів при розслідуванні вимагань: дис. ... канд. юрид. наук: 12.00 .10 / Національна юридична академія України ім. Ярослава Мудрого. Харків, 2006. 214 с.

10. Кримінальний процесуальний кодекс України: Закон України від 13.04.2012 p. № 4651- VI. Дата оновлення: 28.11.2019. URL: https:/ / zakon.rada.gov.ua/law s/show/4651-17.

11. Нор В. Т., Когутич I. І., Павлишин А. А. Прокурорський нагляд в Україні: курс лекщій для студентів юридичних вищих навчальних закладів / за ред. В. Т. Нора. Київ: Атіка, 2004. 352 с.

12. Михайленко О. Р. Прокуратура України: підручник 2-ге вид., перероб. та доп. Київ: Юрінком Інтер, 2011. 336 с.

13. Дворник А. А. Організація роботи прокуратури з нагляду за дотриманням законів у процесі досудового розслідування доведення до банкрутства: дис. ...канд. юрид. наук: 12.00.10/ Акад. адвокатури України. Київ, 2015. 199 с.

\section{References:}

1. Bezpeka na dorozi stosuietsia kozhnoho. V Ukraini startuvav tyzhden bezpeky dorozhnoho rukhu OON: Ministerstvo Okhorony Zdorov'ia Ukrainy. (2019). URL: https:// moz.gov.ua/article/news/bezpeka-na-dorozi-stosuetsja-kozhnogo-v-ukrainistartuvav-tizhden-bezpeki-dorozhnogo-ruhu-oon [in Ukrainian].

2. Slovnyk ukrainskoi movy (1970-1980). (Vols. 1-11); Vol. 9. I. K. Bilodid (Ed.). Kyiv: Naukova dumka. [in Ukrainian].

3. Pivnenko, V.P. (2008). Prokurorskyi nahliad v Ukraini. Kharkiv: Kharkiv Yurydychnyi. [in Ukrainian].

4. Kurochka, M. Y., Karkach, P. M. (2004). Prokurorskyi nahliad v Ukraini. E. O. Didorenko (Ed.). Luhansk: RVV LDUVS. [in Ukrainian].

5. Stepanov, A. B. (2018). Spivvidnoshennia prokurorskoho nahliadu, vidomchoho ta sudovoho kontroliu pid chas dosudovoho rozsliduvannia. Candidate's thesis. Kharkiv. [in Ukrainian]. 
6. Ivanytskyi, S. O. (2018). Rol prokurora v zabezpechenni zakonnosti zatrymannia osoby za pidozroiu u vchynenni zlochynu. Visnyk Luhanskoho derzhavnoho universytetu vnutrishnikh sprav imeni E.O. Didorenka - Bulletin of the Luhansk State University of Internal Affairs Didorenko, 4, 102-108.[in Ukrainian].

7. Farynnyk, V. I. (2018). Teoretychni, pravovi ta prakseolohichni problemy zastosuvannia zakhodiv zabezpechennia kryminalnoho provadzhennia v kryminalnomu protsesi Ukrainy. Doctor's thesis. Kyiv. [in Ukrainian].

8. Hrytsaienko, L. R. (2007). Konstytutsiino-pravovyi status prokuratury Ukrainy. Kyiv: Binovator. [in Ukrainian].

9. Melnyk, O. V. (2006). Problemy prokurorskoho nahliadu za doderzhanniam zakoniv pry rozsliduvanni vymahan. Candidate's thesis. Kharkiv. [in Ukrainian].

10. Kryminal'nyy protsesual'nyy kodeks Ukrayiny: Zakon Ukrainy vid 13.04.2012 r. № 4651 VI. Data onovlennia: 28.11.2019. URL: https:/ / zakon.rada.gov.ua/laws/show/ 4651-17. [in Ukrainian].

11. Nor, V. T., Kohutych, I. I., Pavlyshyn, A. A. (2004). Prokurorskyi nahliad v Ukraini: kurs lektsii dlia studentiv yurydychnykh vyshchykh navchalnykh zakladiv. V. T. Nor (Ed.). Kyiv: Atika. [in Ukrainian].

12. Mykhailenko, O. R. (2011). Prokuratura Ukrainy. Kyiv: Yurinkom Inter. [in Ukrainian].

13. Dvornyk, A. A. (2015). Orhanizatsiia roboty prokuratury $\mathrm{z}$ nahliadu za dotrymanniam zakoniv u protsesi dosudovoho rozsliduvannia dovedennia do bankrutstva. Candidate's thesis. Kyiv. [in Ukrainian].

Стаття надіӥшла до редколегії 16.11.2019

Фурсов Д. Ю., аспирант кафедры организации правоохранительных и судебных органов Луганского государственного университета внутренних дел имени Э. А. Дидоренко (г. Северодонецк, Украина)

\section{СУЩНОСТЬ, ПРЕДМЕТ И ПРЕДЕЛЫ ПРОКУРОРСКОГО НАДЗОРА ЗА СОБЛЮДЕНИЕМ ЗАКОННОСТИ ВО ВРЕМЯ ДОСУДЕБНОГО РАССЛЕДОВАНИЯ УГОЛОВНЫХ ПРАВОНАРУШЕНИЙ ПРОТИВ БЕЗОПАСНОСТИ ДОРОЖНОГО ДВИЖЕНИЯ}

В статье исследована сущность, предмет, объект и пределы прокурорского надзора, на основании чего сформулировано понятие сущности, предмета, объекта и приделов прокурорского надзора за соблюдением законности в ходе досудебного расследования уголовных преступлений против безопасности дорожного движения, а именно преступлений, предусмотренных ст. 286 УК Украины. Сформированы и проанализированы принципы процессуальной деятельности следователя, которые являются элементом предмета прокурорского надзора за соблюдением законности в ходе досудебного расследования уголовных преступлений против безопасности дорожного движения (ст. 286 УК Украины).

Ключевые слова: прокурор, процессуальное руководство, прокурорский надзор, досудебное расследование, дорожно-транспортное происшествие. 
Fursov D.,

Postgraduate Student at the Department of organization of law enforcement and Judicial authorities of Lugansk State University of Internal Affairs named after E. O. Didorenko

(Sievierodonetsk, Ukraine)

\section{THE NATURE, SUBJECT AND LIMITS (BORDERS) OF THE PROSECUTOR'S SUPERVISION OF THE OBSERVANCE OF THE RULE OF LAW IN THE PRE-TRIAL INVESTIGATION OF CRIMINAL OFFENSES AGAINST ROAD SAFETY}

The article explores the basic foundations of the theory of prosecutorial supervision, on the basis of which the notion of the essence, object, object and limits of prosecutorial supervision over the observance of lawfulness during the pre-trial investigation of criminal offenses against traffic safety, namely crimes under Art. 286 of the Criminal Code of Ukraine. The principles of procedural activity of the investigator (the principle of completeness of the course of the investigation, the principle of impartiality of the investigation, the principle of the speed of the investigation, the principle of efficiency), which are an element of the subject of prosecutorial supervision over compliance with the law during the pre-trial investigation of criminal offenses against traffic offenses against traffic offenses against the movement.

Formed content supervision of the legality during the pretrial investigation of criminal offenses against road safety, elements of which are: to identify violations of the laws of the investigator during the preliminary investigation of this category of criminal offenses, directing the course of the investigation and validation, feasibility and timeliness of establishing people, actions are perceived offense under Art. 286 Criminal Code of Ukraine, taking measures regarding redress that would ly limited during pre-trial investigation of criminal offenses under Art. 286 of the Criminal Code of Ukraine; verification of compliance with laws investigator in decision-making (art. 290 or art. 284 CCP Ukraine).

Key words: public prosecutor, judicial guidance, public prosecutor's observation, pretrial investigation, road accident. 